\title{
Human Resource Management, Organizational Performance, and Publicness: The Case of Korean Higher Educational Institutions
}

\author{
Taeyeon Kim*
}

\begin{abstract}
This study investigates the relationship between human resource management and organizational performance using a dataset of 155 universities in Korea. It also examines the moderating effect of publicness measured by ownership (whether it is a public or private university) on the relationship of human resource management and performance. The results show that there is a positive relationship between the efforts of top managers to improve human resource management and one of the two research performance indicators examined in this study. Also, the moderating effects of publicness on the relationship between human resource management and performance are clearly shown in the analysis of both research performance indicators, which means that human resource management in public universities is more conducive to research performance than in private universities. The findings of the present study imply a linear linkage between human resource management and organizational performance and the moderating role of publicness in the management-performance linkage.
\end{abstract}

Keywords: human resource management, organizational performance, publicness

\section{INTRODUCTION}

Multiple empirical studies over the last twenty years have firmly established that the actions of public managers shape organizational outcomes. Meier and O'Toole's research on educational institutions in Texas has attracted particular attention (for an overview, see O'Toole \& Meier, 2011). Since the late 1990s, they have reported important and interesting findings on the relationship between management and performance. For many students of public administration, Meier and O'Toole's findings are now

\footnotetext{
* Taeyeon Kim is a doctoral candidate in the Graduate School of Public Administration at Seoul National University. E-mail: ktypong@snu.ac.kr.
}

Manuscript received June 23, 2016; out for review July 10, 2016; review completed August 6, 2016; accepted August 6, 2016.

The Korean Journal of Policy Studies, Vol. 31, No. 2 (2016), pp. 41-69.

(C) 2016 by the GSPA, Seoul National University 
considered to be crucial evidence supporting the long-held dictum that management matters. Although many researchers from England, Canada, Denmark, and Colombia have recently examined the management-performance nexus in countries other than United States (Andersen \& Mortensen, 2010; Avellaneda, 2009; Johansen \& LeRoux, 2012; Walker, Boyne, \& Brewer, 2010), direct and systematic research on this topic in Korea has been rare (see Song \& Chun, 2014).

In the present study, I examine the idea of a management-performance nexus using a dataset of 155 Korean universities (four-year colleges). Meier and O'Toole's original model of the management-performance nexus incorporates two major dimensions of management, external management (networking behavior) and internal management. I concentrate here on the internal management of human resources that may influence organizational performance. I have chosen the research setting of higher educational institutions, because higher education is generally viewed as an important public service sector in many countries and because the field of higher education has a relatively high level of consensus when it comes to identifying performance indicators of universities. In the areas of education and research in universities, there are agreed-on and objective indicators of performance, which most public service organizations subject to performance ambiguity do not have the luxury of (Chun, 2004).

In addition to investigating the relationship between human resource management and performance, this study tests another theoretical argument, which has not yet been examined empirically, about the moderating role of publicness on the relationship, which figures in Meier and O'Toole's theory (2011). The rest of this article is organized as follows. First, I discuss the literature on this topic and describe data sources and the measurement of variables in this study, and then I present the results of the analysis. I conclude with a discussion of the findings and the implications for future research.

\section{LITERATURE REVIEW}

Meier and O'Toole first developed a formal model of the management-performance nexus in 1999 and have tested the model, using a dataset of Texas school districts and their superintendents, for more than 10 years. This model is as follows:

$$
O_{t}=\beta_{1}\left(S+M_{1}\right) O_{t-1}+\beta_{2}(X t / S)\left(M_{3} / M_{4}\right)+\varepsilon_{1}
$$

$O$ is a measure of outcome. $S$ is a measure of stability. $M$ denotes management divided into three parts $-M_{1}$ is management's contribution to organizational stability through additions to the hierarchy/structure as well as regular operations, $M_{3}$ is 
management's efforts to exploit the environment, $M_{4}$ is management's effort to buffer environmental shocks. $X$ is a vector of environmental forces. $E$ is an error term. The other subscripts denote time periods; and $\beta_{1}$ and $\beta_{2}$ are estimable parameters (Meier \& O'Toole, 2007).

As clearly shown in the model, O'Toole and Meier consider internal management $\left(M_{1}\right)$ a key dimension of management in their theorization, but much of their empirical work has focused on the external management of the organizations (Meier \& O'Toole, 2001, 2003, 2005; O’Toole \& Meier, 2004, 2006; O'Toole, Walker, Meier, \& Boyne, 2007). Substantially less attention has been paid to what managers do inside their organizations to shape performance (see O'Toole and Meier, 2009). Despite the relative paucity of research, however, the notion that effective management inside organizations is conducive to performance has been a conventional wisdom in the field of public administration.

Internal management can be conceptualized in a number of ways because it refers to a wide range of activities inside organizations including human and financial resources management, culture shaping, and work unit structuring. Among these activities, the effort of attracting, keeping, developing, and motivating people at all levels in organizations, that is, human resource management, is arguably a core function of management in public organizations (Bertelli \& Lynn, 2006; Nigro \& Kellough, 2006; Shafritz et al., 2001).

Human resource management's impact on organizations' performance is surely one of the most important and frequently discussed topics by scholars of public administration (Ingraham, Selden, \& Moynihan, 2000; Nigro \& Kellough, 2006; Selden \& Jacobson, 2007; Cho \& Yoon, 2009) and business administration (Koch \& McGrath, 1996; Li, 2000; Wood, 1999). O’Toole and Meier (2009) have also focused on human resource management, estimating its effect on organizational performance. ${ }^{1}$ Ideally, research on public organizations would encompass all facets of internal management, but doing so in a single study is not feasible (O'Toole \& Meier, 2009). This study focuses here on the management of human resources because public organizations are mostly labor intensive, and the efforts of many professionals are clearly crucial to performance. It is clear that the ability to recruit, train, and retain professionals in a competitive labor market is positively related to performance, which in turn requires

1. Internal management involves several responsibilities from designing and operating information systems, to managing financial resources, to motivating and leading employees, and more. However it is very difficult for researchers to test for the performance-related effects of them all. O'Toole and Meier (2009) isolated one aspects of internal management: human resource management and estimated its effects on organizational outputs and outcomes. 
dedicated management. ${ }^{2}$ The focus of this study on human resource management in public organizations leads to the generation of hypothesis 1 .

Hypothesis 1: Managers in organizations that devote more effort to human resource management will generate higher levels of organizational performance.

Although scholars in both public administration and business administration have emphasized the impact of human resource management on organizational performance (Jacobs \& Washington, 2003; Wood, 1999; Koch \& McGrath, 1996), studies directly comparing public and private human resource management are rare. ${ }^{3}$ In their 2007 study, Meier and O'Toole do not address the difference between public and private organizations in the course of building their model and only include public organizations in their empirical analysis. In a 2011 study, however, they explore "publicness and organizational performance," making new theoretical assumptions and generating hypotheses that supplement the idea of publicness as a moderator in the managementperformance nexus. These hypotheses support Sayre's well-known aphorism that the public and private sectors are "alike in all unimportant respects" (1958, p. 245). The assumptions of internal management, $M_{1}$, are as follows: ${ }^{4}$

Assumption 1: $\sigma\left(M_{b i}\right)>\sigma\left(M_{o i}\right)$. The kinds of actions that management can take inside organizations $\left(M_{1}\right)$ in the public sector is more limited than the kinds of actions that managers can take in the private sector.

Assumption 2: and $\beta_{b 1}<\beta_{o 1}$ and $\beta_{o 1} \rightarrow 1$.0. Government organizations are generally characterized as highly stable and so may be expected to produce the same outputs in perpetuity.

2. If human capital should matter anywhere it should matter in educational organizations, "coping" organizations in the parlance of Wilson (1989), whose production functions have been extensively studied (O'Toole \& Meier, 2009). This is why this analysis focuses only on higher educational institutions.

3. Budhwar and Boyne (2004) reveal that the gap between Indian private- and public-sector human resource management practices is not very significant, but their study is not about human resource management's impact on performance. Boyne, Jenkins and Pool (1999) present the results of an extensive survey of managers in the public and private sectors in an effort to assess whether there are significant differences between human resource management in the two sectors. However, their study likewise does not address the issue of human resource management's impact on performance.

4. Meier and O'Toole (2011)'s specific model is as follows: $O_{o t}=\beta_{o 1}\left(S_{o 1}+M_{o 1}\right) O_{o t-1}+\beta_{o 2}$ $\left(X_{o t} / S_{o z}\right)\left(M_{o 3} / M_{o 4}\right)+\varepsilon_{o t}$ for public organizations and $O_{b i}=\beta_{b 1}\left(S_{b 1}+M_{b 1}\right) O_{b t-1}+\beta_{b 2}\left(X_{b i} /\right.$ $\left.S_{b z}\right)\left(M_{b 3} / M_{b 4}\right)+\varepsilon_{b i}$ for private organizations. They suggest some theoretical hypotheses focusing on the differences between public and private organizations based on the assumptions generally proved from earlier research. 
These assumptions lead to the generation of hypothesis 2: $\delta O_{d} / \delta M_{1}>\delta O_{b} / \delta M_{1}$, which means that "internal management will matter more in public organizations." The relative impact of internal managerial change will be greater in a public organization than in a private organization (Meier \& O'Toole, 2011). The impact of a one-unit change in management is $\beta_{2}$, so $O_{t}$ increases by $\beta_{2}$, and for the next year $O_{t+1}$ increases by an additional $\beta_{1} \times \beta_{2}$. These impacts continue into the future at a geometrically declining rate (Meier \& O'Toole, 2011). The closer $\beta_{2}$ is to 1.0 and all things being equal, internal management changes will have a greater impact on the performance of public organizations than on private organizations (Meier \& O'Toole, 2011). ${ }^{5}$

Favero, Meier, and O'Toole (2014) argue that internal management matters more in public organizations because the actions of public managers are more constrained than those of their private counterparts by laws, regulations, and the influence of political principals. ${ }^{6}$ Certainly, managers' ability to control material incentives is much more limited than in the private sector, so they must rely on normative and solidary inducements to shape employee actions (O'Toole \& Meier, 2015; Wilson, 1989). Public managers must seek to create a work environment, norms, and culture that encourage street-level bureaucrats to improve the quality of their performance (May \& Winter 2009; Maynard-Moody \& Musheno 2003; Tummers \& Bekkers 2014).

Much attention has been devoted to the assertion that the limited discretion of public managers undermines organizational performance (for extensive documentation, see Rainey, 2014). Public managers are expected to be more concerned with fairness, transparency, accountability, and so forth than with efficiency and effectiveness, compared to private managers, which means they are limited when it comes to selecting management tools. They are left with insufficient authority over pay, promotion, and discipline, which are all related to human resource management. Consequently, the constraints on public managers create weak links between human resource management and performance in public organizations and hence undermine performance.

It may be therefore be assumed that human resource management has less of an

5. According to Meier and O'Toole (2011), it is still possible that the total contribution of management to the performance of private sector organizations exceeds the total contribution of management to public sector organizations. This hypothesis simply indicates that for the same type of internal management, a one-unit increase will have a larger impact on performance in the public sector than in the private sector.

6. Favero et al. (2014) examine the performance of New York City schools between 2007 and 2009. During this time period, the schools in New York City were undergoing a major reform. The reforms greatly expanded the authority of principals and significantly increased schools' accountability for performance. These reforms also stressed parental involvement and the engagement of teachers. 
impact on performance in public organizations than in private organizations. Arnaud and Wasieleski (2014) suggest it is possible that human resource management may only influence performance if managers have full discretion. In addition, Guest and Woodrow (2012) point out that human resource management affects organizational performance in the form of managers' efforts to influence to workers' attitude and behavior.

Nonetheless, it cannot be concluded from this that the impact of human resource management on organizational performance will be greater in public organizations than in private organizations The difference between human resource management in public and private organizations has a differential impact on organizational performance, an impact that is not sufficiently accounted for by Favero et al. (2014).

Overall, the proposition that publicness can moderate the management-performance nexus is left unexplained theoretically or empirically, and many additional studies on this issue are needed. This article provides some statistically significant support for this argument and hence suggests an exploratory hypothesis that is neither affirmed nor denied. This leads to the generation of hypothesis 2 .

Hypothesis 2: The degree of the moderating effect of human resource management on performance will vary depending on the publicness of an organization.

\section{RESEARCH DESIGN}

\section{Samples}

The unit of my analysis is Korean higher educational institutions-more specifically, all universities in Korea. I have picked this as the unit of analysis for several reasons. First, higher education is a major policy area in which both public and private organizations provide the same kind of services. This makes it possible for us to explore the relationship among management, performance, and publicness. Second, higher education is one of the most representative organizations that are supported by the government in various ways, including with public funding. Third, there are databases that provide objective empirical sources with a significant number of well-developed performance indicators - both in education and research.

The population of my analysis is 270 universities, which includes every university in Korea, and the data come from two sources: the 2014 survey of Korean public service organizations is the source of the independent variables and the Higher Education in Korea website (www.academyinfo.go.kr) is the source of the dependent and control variables. 
The Center for Organizational Diagnosis and Evaluation Research at Seoul National University conducted the survey of Korean public service organizations in 2014, which encompassed universities, general hospitals, and research institutions. The survey data were procured through face-to-face interviews with the two middle managers who can be assumed to have been professionals in personnel and finance departments. ${ }^{7}$ Of the 270 universities contacted for the survey, 191 responded; thus the approximate return rate was $70.7 \%$. After excluding cyber universities, Korea national open university and universities with less than 40 full-time faculty members (approximately $8 \%$ of 191), I was left with a final dataset of 155 universities. I excluded these types of universities because they could be outliers in the dataset due to their specific functions or small size.

\section{MEASURES}

\section{Dependent Variables: Organizational Performance}

The functions of universities are broadly divided into two parts, education and research, and their performance is commonly measured separately according to these two key functions (Kim, Shim, \& Lee, 2013).

The most authoritative database for information on Korean universities can be found at the Higher Education in Korea website; this database has been constructed in accordance with Korean law that specifies how public information on higher educational institutions is to be released. The dataset for the dependent variables was likewise collected from the Higher Education in Korea website, in particular, from the data released in 2015. The reason this study uses the 2015 dataset is to account for the time lag. More precisely, I have sought to incorporate the assumption that for the next year, $O_{t+1}$ will increase by an additional $\beta_{1} \times \beta_{2}$, following Meier and O'Toole (2011).

To measure educational performance, this study employs two indicators: the employment rate of college graduates and the student retention rate. ${ }^{8}$ The employment rate of college graduates is the representative and typical indicator used to broadly measure educational performance, while the student retention rate (the opposite of the

7. In a university, the middle managers in department of personnel and finance are deeply engaged in internal management and so will have plenty of knowledge of its workings. Therefore they are professional enough in my view to be the target of a survey.

8. The Higher Education in Korea website only releases the number of college graduates who are employed. I obtain the employment rate by dividing the number of employed students by recent graduates. 
dropout rate) is a widely acknowledged indicator that conveys the degree of students' satisfaction and determines whether they will remain at the university. ${ }^{9}$

This study also employs the number of articles published in foreign journals and the number of articles published in Korean journals per full-time faculty as research performance indicators. Research performance, both in quality and quantity, is usually measured by the achievements of full-time faculty members. The most frequent quantity indicator is the number of published articles (Dundar \& Lewis, 1998; Lovegrove \& Johnson, 2008). The Higher Education in Korea website releases information pertaining to various types of achievements per full-time faculty member. In this study, I have tried to cover the achievements in terms of both quality and quantity and hence selected two indicators, the number of articles published in Korean journals that are or will be listed by the National Research Foundation of Korea (NRFK) per full-time faculty member and the number of articles published in foreign journals listed in the Science Citation Index (SCI) or Scopus per full-time faculty member. ${ }^{10}$

\section{Independent Variable: Human Resource Management}

Internal management can be characterized in terms of a wide array of dimensions. In particular, the internal management of public organizations focuses heavily, of necessity, on the "human side" (McGregor, 1960), simply because incentive-focused strategies in management are limited in the public sector (see Feeney \& Rainey, 2010). This study seeks to tap into the human side: attracting, developing, motivating, and evaluating people. In a 2009 study, O'Toole and Meier report the results of a survey of superintendents (top managers) who were asked to rate the quality of principals' (middle managers and subordinates who are being managed by top managers) management. However, because their responses might be subject to social desirability bias (since top managers tend to judge themselves mostly in a positive way) and because what top

9. The employment rate of college graduates indicates directly way how many qualified students there are and the quality of education indirectly (Kim, 2009). This measure is the criteria that is commonly used to evaluate universities in Korea, especially by the government for purposes of deciding the amount of funding it will provide. Lewis and Smith (1994) suggest using students' academic outputs, the rate of college graduates, and the dropout rate as performance indicators. The Higher Education in Korea website only releases the dropout rate so I calculated the student retention rate by subtracting the dropout rate from 100.

10. Dundar and Lewis (1994) assert that only the articles published in qualified journals should be counted as research for performance assessment purposes. 
managers think they are doing and what their subordinates think they are doing might be two different things, this study measures top managers' management actions using the perceptions of middle managers who are being managed because that may provide a more unbiased measure than the one measured by the perceptions of top managers themselves.

The questionnaire measuring human resource management in the 2014 survey of Korean public service organizations focused on top managers. Five survey items (communication, improvement of welfare, settlement of complaints, motivation, and development) were used to obtain the perception of middle managers on a five-point scale (from $1=$ makes little effort to $5=$ makes a great effort). ${ }^{11}$

The composite measure of the perceptions of the two managers who were interviewed is more reliable than one individual's perception would be. Here I use the average of the two perception scales and the factor loadings of five survey items to extract a common core concept of human resource management. A factor analysis produced a single common factor, a composite measure of the five items, and the Cronbach alpha for this scale was .9222. Accordingly, this factor score is the final independent variable for human resource management.

\section{Moderating Variable: Publicness}

Public and private organizations are primarily distinguished from each other in terms of who owns, funds, and controls them (see Perry \& Rainey, 1988). Each aspect of publicness has a separate effect on performance, and studies using more than two of them are rare (Andrews, Boyne, \& Walker, 2011). This study employs ownership as the indicator of publicness. Accordingly, the moderating variable is the dummy variable taking the value 1 if it is a public university and 0 if it is a private university. ${ }^{12}$

The higher education law in Korea establishes what qualifies a university as public or private. There are considerable differences that pertain to how each are organized, the

11. According to several studies on human resource management, it typically refers to the task of attracting, keeping, developing, and motivating people at all levels in organizations (Bertelli \& Lynn, 2006; Nigro \& Kellough, 2006; Shafritz et al., 2001). This study analyzes communication, improvement of welfare, settlement of complaints, motivation, and development as independent variables because they match these core concepts of human resource management.

12. This study includes national universities, corporate national universities, special corporate universities, special corporate national universities, and municipal universities in the dataset of public universities. 
degree of power they have, and the nature of decision making at each. ${ }^{13}$ It is assumed that ownership can operate as a moderator in the management-performance nexus.

\section{Control Variables}

In assessing the impact of the internal management of human resources on organizational performance and the moderating effect of publicness, I have included a set of controls to adjust for both the variance in environmental constraints on a university and the resources that it has at its disposal. The variables that may pertain to the national context should be also included. It is essential to show that the effect of human resources management on performance and the moderating effect of publicness measured here is unique and not a function of other variables.

Many studies have shown that environmental constraints negatively influence performance (Chun \& Kum, 2011). Meier and O'Toole's model includes the percentage of students who are black, Latino, and poor, a variable that is measured by the percentage who are eligible for a free or reduced-price school lunch. In this study, I use two measures as constraints: the rate at which students take out loans for school expenses and the location of a university. ${ }^{14}$ Three measures are included as resources: the number of students per full-time faculty member; the size of the organization, and the age of the organization. Two measures are included to take account of context: whether or not the university has a college of engineering or medicine and the publicness ( 1 if it is a public university and 0 if it is a private university). ${ }^{15}$ All of these factors have been shown to influence performance in public organizations.

A growing body of literature of well-designed studies has confirmed that organiza-

13. Per article 3, section 1 , of the Korean higher education act, universities in Korea are divided into two categories, national $\cdot$ municipal and private. Public universities are established and regulated by the Ministry of Education, Science, and Technology; private universities are established and overseen by corporations or an individual. According to the private school act, a private university is invested with autonomy (Bae et al., 2012).

14. I obtain the rate of student loans by dividing the number of students who have taken out loans for tuition by the number of enrolled students.

15. Lee, Kwak, and Lee (2003) divide universities into three categories: universities that have both medical and engineering schools, universities that have either a medical school or an engineering school, and universities that have neither. Ahn, Cho, and Park (1998) evaluate the efficiency of universities in Korea and confirm differences depending on whether a university has a college of engineering or medicine or not. Lee (2001) likewise demonstrates that the accounting performance of a university differs according to whether it has an engineering or medical school. 
tions with more resources generally are far better. In this study, I have used the number of students per full-time faculty member, organizational size measured as log scores of the whole number of students, and organizational age to measure of the extent of the resources of a university. ${ }^{16}$ Publicness is considered the moderating variable in my analysis, and I also include it as a control variable because publicness itself can have significant influence on the performance of Korean universities. ${ }^{17}$

\section{Method}

Estimations were developed using multiple regression analysis for each of the four performance indicators: the employment rate of college graduates, the student retention rate, the number of articles published in foreign journals per full-time faculty member and the number of articles published in Korean journals per full-time faculty member. All four regression analyses included the same independent, moderating, and control variables listed in table 1 . This study focuses here on the moderating effect of publicness in the management-performance nexus as measured by hierarchical regression analysis. ${ }^{18}$ In the first modeling stage, I conducted a regression analysis with only control variables, and in the second modeling stage, I included the independent variable, human resource management, in each regression analysis. In the final modeling stage, I included publicness, and I tried to reveal the presence of a moderating effect in each regression analysis.

The interaction term is used in the estimation of the moderating effect, which can

16. The number of students per teacher is typically referred to as "class size." It can be inferred that the lower the number of students per teacher, the greater an abundance of resources an organization has. Class size should be negatively related to student performance. In this article, the unit of analysis is Korean universities, so I employ the number of students per full-time faculty member. Scholars suggest two theories about organizational size. Big organizations have an advantage if they can maintain economy of scale (Daft 2012), but transaction costs by the same token can put them at a disadvantage (Williamson, 1975: 2630). Many studies, including Jang (2002) and Lee and Kim (2007), report that well-known universities tend to perform better than lesser known ones. Older universities tend to be better known than more recently founded universities, so organizational age can serve as a proxy measure for how well known an institution is in our analysis.

17. The Korean Educational Development Institution (KEDI, 2008) reports that representative performance indicators vary depending on whether a university is public or private and that most of the performance indicators in public universities are superior.

18. The explanation of moderating effect should be based on the increment when I add the interaction term in the hierarchical regression analysis (Jo, Y. I., Kim J. H., Han. W. L., \& Jo. Y. J., 2015). 
cause a multicollinearity problem. Variance inflation factor tests of all the variables were conducted, and it was confirmed that the possibility of multicollinearity is quite low, scoring less than 10. I used the list-wise selection method to drop observations with missing values from 155 observations, and I confirmed a minimum total of 128 observations.

\section{FINDINGS}

\section{Descriptive Statistics and Correlations}

Descriptive statistics for all variables are shown in table 1, and the results of all variables' correlations are listed in table 2 . Some negative correlations among performance

Table 1. Descriptive Statistics

\begin{tabular}{|c|c|c|c|c|c|c|}
\hline & Variables & Obs. & Mean & Std. Dev. & Min. & Max. \\
\hline \multicolumn{7}{|c|}{ Dependent Variables } \\
\hline \multirow{2}{*}{ Education } & employment rate & 142 & 55.458 & 12.944 & 7.143 & 100 \\
\hline & retention rate & 151 & 95.323 & 2.926 & 82.9 & 100 \\
\hline \multirow{2}{*}{ Research } & $\begin{array}{l}\text { number of articles } \\
\text { published in Korean } \\
\text { journals per full-time } \\
\text { faculty member }\end{array}$ & 150 & 0.553 & 0.253 & 0.018 & 1.542 \\
\hline & $\begin{array}{l}\text { number of articles } \\
\text { published in foreign } \\
\text { journals per full-time } \\
\text { faculty member }\end{array}$ & 150 & 0.212 & 0.223 & 0 & 1.387 \\
\hline \multicolumn{7}{|c|}{ Independent Variables } \\
\hline human $r$ & source management & 128 & 0.038 & 1.008 & -4.193 & 2.476 \\
\hline \multicolumn{7}{|c|}{ Moderating Variables } \\
\hline publicne & & 155 & 0.329 & 0.471 & 0 & 1 \\
\hline \multicolumn{7}{|c|}{ Control Variables } \\
\hline \multicolumn{2}{|c|}{ rate of borrowing } & 136 & 16.054 & 5.897 & 0 & 35.586 \\
\hline \multicolumn{2}{|l|}{ location } & 155 & 0.232 & 0.424 & 0 & 1 \\
\hline \multicolumn{2}{|c|}{ age of organization } & 154 & 44.253 & 26.428 & 2 & 117 \\
\hline \multicolumn{2}{|c|}{ number of students } & 149 & 23.852 & 8.252 & 1.302 & 42.025 \\
\hline \multicolumn{2}{|c|}{ size of organization } & 150 & 8.539 & 0.965 & 5.911 & 10.123 \\
\hline \multicolumn{2}{|c|}{ school of engineering } & 151 & 0.815 & 0.390 & 0 & 1 \\
\hline \multicolumn{2}{|c|}{ school of medicine } & 151 & 0.219 & 0.414 & 0 & 1 \\
\hline
\end{tabular}




\begin{tabular}{|c|c|c|c|c|c|c|c|c|c|c|c|c|c|}
\hline$\stackrel{\mathbb{I}}{=}$ & & & & & & & & & & & & - & \begin{tabular}{l}
$\mathscr{Q}$ \\
\multirow{0}{0}{} \\
0
\end{tabular} \\
\hline $\bar{E}$ & & & & & & & & & & & - & 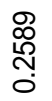 & 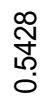 \\
\hline 을 & & & & & & & & & & - & $\begin{array}{l}0 \\
\text { Oे } \\
\text { Ő } \\
0\end{array}$ & $\begin{array}{l}\text { 苟 } \\
\text { लొ } \\
0\end{array}$ & 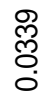 \\
\hline ( & & & & & & & & & - & $\begin{array}{l}0 \\
0 \\
\text { O } \\
\\
\\
\end{array}$ & 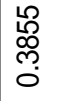 & $\frac{\stackrel{0}{0}}{\frac{m}{0}}$ & 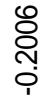 \\
\hline$\Phi$ & & & & & & & & - & $\begin{array}{l}\stackrel{0}{\mathscr{D}} \\
\stackrel{\mathrm{N}}{\leftarrow} \\
\end{array}$ & $\frac{+}{0}$ & 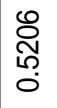 & 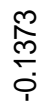 & 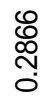 \\
\hline$E$ & & & & & & & - & $\frac{\hat{0}}{\frac{0}{\phi}}$ & 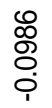 & $\begin{array}{l}\text { \&্ } \\
\text { ஸ़ } \\
\text { o }\end{array}$ & 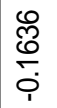 & $\begin{array}{l}\text { Nọ } \\
\text { ọ }\end{array}$ & 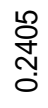 \\
\hline (Q) & & & & & & - & $\begin{array}{l}\stackrel{N}{\mathscr{g}} \\
\stackrel{0}{0}\end{array}$ & 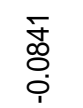 & 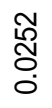 & $\frac{\frac{10}{\hat{L}}}{\frac{1}{0}}$ & 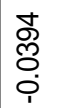 & 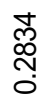 & 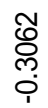 \\
\hline [0 & & & & & - & $\begin{array}{l}\text { 오 } \\
\text { مِ } \\
0\end{array}$ & $\begin{array}{l}\text { No } \\
\text { do } \\
\text { o }\end{array}$ & $\begin{array}{l}\text { స్ల } \\
\text { O্ }\end{array}$ & 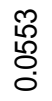 & 衣 & $\begin{array}{l}\text { ్․ } \\
0 \\
0 \\
0 \\
0\end{array}$ & $\begin{array}{l}\mathscr{Q} \\
\mathscr{0} \\
\varnothing \\
0\end{array}$ & $\begin{array}{l}\text { N } \\
\text { O } \\
0 \\
0\end{array}$ \\
\hline 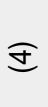 & & & & - & $\begin{array}{l}\mathscr{O} \\
\text { N̦ } \\
\text { O }\end{array}$ & $\begin{array}{l}\text { ஜ్ } \\
\text { d } \\
0 \\
0\end{array}$ & 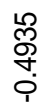 & $\begin{array}{l}\text { Oे } \\
\text { స్ } \\
\text {. }\end{array}$ & $\begin{array}{l}\mathscr{O} \\
\stackrel{\mathscr{N}}{0} \\
\stackrel{0}{0}\end{array}$ & 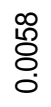 & 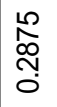 & $\frac{\mathscr{C}}{\stackrel{0}{0}}$ & $\begin{array}{l}\text { D } \\
\text { m } \\
0 \\
\text { co }\end{array}$ \\
\hline હ্ & & & - & 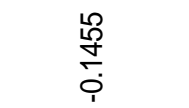 & $\begin{array}{l}0 \\
\text { \& } \\
\text { i }\end{array}$ & $\begin{array}{l}\stackrel{D}{0} \\
\text { m } \\
0\end{array}$ & 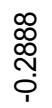 & $\frac{\frac{0}{n}}{\frac{10}{0}}$ & $\begin{array}{l}\text { ஜ } \\
\text { ơ } \\
\text { : }\end{array}$ & $\frac{\widetilde{N}}{\frac{\pi}{0}}$ & $\frac{10}{0}$ & 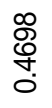 & $\frac{0}{\frac{0}{0}}$ \\
\hline$\widetilde{\mathbb{N}}$ & & - & $\begin{array}{c}\stackrel{0}{N} \\
\substack{m \\
0}\end{array}$ & 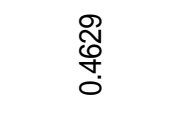 & $\frac{\stackrel{\infty}{\stackrel{+}{\sim}}}{\stackrel{0}{+}}$ & $\begin{array}{c}\underset{N}{N} \\
\text { N } \\
0\end{array}$ & 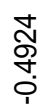 & 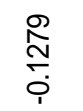 & $\frac{\widetilde{N}}{\stackrel{N}{0}}$ & 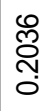 & 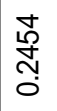 & 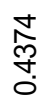 & $\frac{\bar{N}}{\stackrel{\Gamma}{0}}$ \\
\hline$\Xi$ & - & $\begin{array}{l}\text { 芯 } \\
\text { ָ̦ }\end{array}$ & $\begin{array}{l}\text { ్ָ } \\
\text { N̦ } \\
\text {. }\end{array}$ & $\begin{array}{l}\text { న్ల్ } \\
\text { } \\
\text { }\end{array}$ & 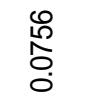 & $\frac{\stackrel{+}{W}}{\stackrel{0}{\circ}}$ & 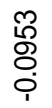 & $\begin{array}{l}\text { I্ } \\
\text { : } \\
\text { ị }\end{array}$ & $\frac{\widetilde{\Phi}}{\frac{\tilde{\sigma}}{0}}$ & 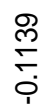 & 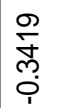 & $\begin{array}{l}\infty \\
\stackrel{\infty}{\circ} \\
0\end{array}$ & $\begin{array}{l}\infty \\
\text { ర్ల } \\
\text { N̦ } \\
\text { pon }\end{array}$ \\
\hline & $E$ & $\widehat{\mathbb{I}}$ & ल) & $\mathcal{E}$ & $\sqrt{0}$ & $\widetilde{\theta}$ & $E$ & $\widehat{\infty}$ & (อ) & 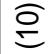 & $\underline{E}$ & $\stackrel{\cong}{\cong}$ & $\stackrel{\bar{m}}{=}$ \\
\hline & 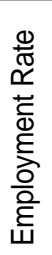 & 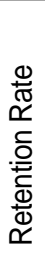 & 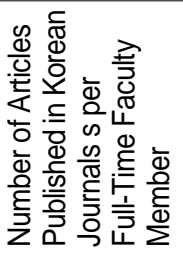 & 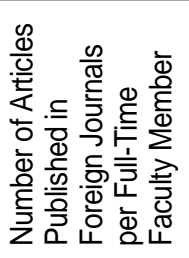 & 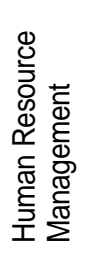 & 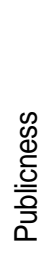 & 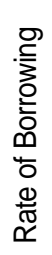 & 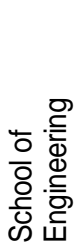 & 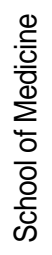 & 등 & 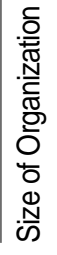 & 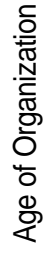 & 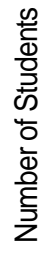 \\
\hline
\end{tabular}


indicators were observed. The correlation between the number of articles published in foreign journals per full-time faculty member and the number of articles published in Korean journals per full-time faculty member is negative and statistically significant ( $\mathrm{p}$-value $=0.0757<0.1$ ). In addition, the correlation between the number of articles published in foreign journals and the employment rate is also negative and even more statistically significant ( $\mathrm{p}$-value $=0.0053<0.01)$. That relationship is an interesting anomaly because it is only shown among performance indicators. These confounding relationships among performance indicators considerably influenced my final analysis, which I document in the concluding section.

\section{RESULTS OF EDUCATIONAL PERFORMANCE}

\section{Employment Rate of College Graduates}

As the results in table 3 demonstrate, human resource management at Korean universities does not have a statistically significant impact on the employment rate, and no moderating effect is found either. In models 1 and 2, as shown in table 3, some control variables are statistically significant in the expected direction.

The results show that the employment rate is higher in universities located outside of Seoul and Gyeonggi-do. This could be due to the fact that the students in Seoul and Gyeonggi-do tend to hold off on taking a job until what they want (Oh, 2010). The size of organization is shown to be negatively related to the employment rate. It could be due to the transaction cost as mentioned in footnote 16. The age of organization is also statistically significant, and hence it can contribute positively to the employment rate.

Aside from these significant findings, other effects of the independent or moderating variables were not observed. Concerning the overall R-square, the model accounts for only $18 \%$ of the total variance. This low R-square could be due to the flawed measure of the employment rate itself. Certainly employment rate is the most representative measure of the educational performance of a university. However, several scholars have indicated limitations in the process of constructing this measure. In particular, the employment rate provided by the Higher Education in Korea website measures employment only in terms of quantity and not in quality. Kwak (2012) points out that employment should be measured to reflect qualities such whether it is full time, whether it is with a major company, whether it is "good enough" employment, whether it coincides with one's major in college, and so forth. 
Table 3. Analysis of Employment Rate of College Graduates ${ }^{19}$

\begin{tabular}{|c|c|c|c|c|c|c|c|}
\hline & \multicolumn{2}{|c|}{ Model 1} & \multicolumn{2}{|c|}{ Model 2} & \multicolumn{2}{|c|}{ Model 3} \\
\hline & & Coef. & Std. Err. & Coef. & Std. Err. & Coef. & Std. Err. \\
\hline \multirow{8}{*}{$\begin{array}{l}\text { Control } \\
\text { Variables }\end{array}$} & rate of borrowing & -0.225 & 0.274 & -0.063 & 0.316 & -0.094 & 0.316 \\
\hline & $\begin{array}{l}\text { number of students per } \\
\text { faculty member }\end{array}$ & 0.099 & 0.220 & 0.163 & 0.255 & 0.170 & 0.257 \\
\hline & school of Engineering & -0.446 & 3.609 & -1.089 & 3.980 & -1.423 & 4.084 \\
\hline & school of Medicine & -1.491 & 3.584 & -1.479 & 4.171 & -1.375 & 4.197 \\
\hline & Location & -4.718 & 3.153 & $-8.566^{\star *}$ & 3.840 & $-8.486^{* *}$ & 3.862 \\
\hline & size of organization & $-5.658^{\star \star \star}$ & 2.156 & $-6.027^{\star *}$ & 2.438 & $-6.006^{\star \star}$ & 2.449 \\
\hline & age of organization & $0.119^{\star *}$ & 0.057 & $0.164^{* *}$ & 0.065 & $0.161^{* *}$ & 0.066 \\
\hline & publicness & -0.873 & 3.416 & -1.521 & 3.898 & -1.884 & 4.018 \\
\hline $\begin{array}{l}\text { Independent } \\
\text { Variables }\end{array}$ & $\begin{array}{l}\text { human resource } \\
\text { management }\end{array}$ & & & 1.120 & 1.231 & 0.852 & 1.405 \\
\hline $\begin{array}{l}\text { Interaction } \\
\text { Term }\end{array}$ & $\begin{array}{l}\text { human resource } \\
\text { management *publicness }\end{array}$ & & & & & 1.207 & 3.010 \\
\hline \multicolumn{2}{|c|}{ Number of Observations } & \multicolumn{2}{|c|}{126} & \multicolumn{2}{|c|}{108} & \multicolumn{2}{|c|}{108} \\
\hline \multicolumn{2}{|l|}{ R-square } & \multicolumn{2}{|c|}{0.1742} & \multicolumn{2}{|c|}{0.1876} & \multicolumn{2}{|c|}{0.1890} \\
\hline \multicolumn{2}{|l|}{$\Delta \mathrm{R}$-square } & \multicolumn{2}{|r|}{-} & \multicolumn{2}{|c|}{0.0134} & \multicolumn{2}{|c|}{0.0014} \\
\hline \multicolumn{2}{|l|}{$\mathrm{F}$} & \multicolumn{2}{|c|}{3.08} & \multicolumn{2}{|c|}{2.51} & \multicolumn{2}{|c|}{2.26} \\
\hline
\end{tabular}

${ }^{*} p<0.1,{ }^{* *} p<0.05,{ }^{* * *} p<0.01$

\section{Student Retention Rate}

As the results in table 4 demonstrate, as with the employment rate, human resource management at Korean universities does not have a statistically significant impact on the retention rate, and a moderating effect is not found either. Compared to the analysis of the employment rate of college graduates, many control variables in this analysis, such as the rate at which students take out loans for school expenses, the location of a university, the size of organization, whether or not the university has a college of engi-

19. In the tables of showing the results, I put the control variables prior to independent variables or interaction terms because this analysis takes the form of a hierarchical regression, which requires mentioning control variables first and then explaining the key findings from independent variables or interaction terms. 
Table 4. Analysis of Student Retention Rate

\begin{tabular}{|c|c|c|c|c|c|c|c|}
\hline & \multicolumn{2}{|c|}{ Model 1} & \multicolumn{2}{|c|}{ Model 2} & \multicolumn{2}{|c|}{ Model 3} \\
\hline & & Coef. & Std. Err. & Coef. & Std. Err. & Coef. & Std. Err. \\
\hline \multirow{8}{*}{$\begin{array}{l}\text { Control } \\
\text { Variables }\end{array}$} & rate of borrowing & $-0.201^{\star \star \star}$ & 0.043 & $-0.233^{\star * *}$ & 0.047 & $-0.225^{\star \star *}$ & 0.049 \\
\hline & $\begin{array}{l}\text { number of students per } \\
\text { faculty member }\end{array}$ & -0.006 & 0.034 & -0.020 & 0.039 & -0.021 & 0.039 \\
\hline & school of Engineering & $-1.536^{\star \star \star}$ & 0.556 & $-1.680^{\star \star *}$ & 0.601 & $-1.610^{\star \star \star}$ & 0.612 \\
\hline & school of Medicine & 0.398 & 0.576 & 0.342 & 0.656 & 0.320 & 0.659 \\
\hline & location & $1.994^{\star \star \star}$ & 0.484 & $1.990^{* \star *}$ & 0.577 & $1.951^{\star * \star}$ & 0.582 \\
\hline & size of organization & $0.639^{*}$ & 0.335 & $0.803^{\star *}$ & 0.371 & $0.803^{\star *}$ & 0.372 \\
\hline & Age of organization Age & 0.013 & 0.009 & 0.013 & 0.010 & 0.014 & 0.010 \\
\hline & publicness & $1.045^{\star}$ & 0.536 & 0.840 & 0.596 & 0.927 & 0.612 \\
\hline $\begin{array}{l}\text { Independent } \\
\text { Variables }\end{array}$ & $\begin{array}{l}\text { human resource } \\
\text { management }\end{array}$ & & & 0.136 & 0.191 & 0.207 & 0.218 \\
\hline $\begin{array}{l}\text { Interaction } \\
\text { Term }\end{array}$ & $\begin{array}{l}\text { human resource } \\
\text { management *publicness }\end{array}$ & & & & & -0.309 & 0.459 \\
\hline \multicolumn{2}{|c|}{ Number of Observations } & \multicolumn{2}{|c|}{133} & \multicolumn{2}{|c|}{114} & \multicolumn{2}{|c|}{114} \\
\hline \multicolumn{2}{|l|}{ R-square } & \multicolumn{2}{|c|}{0.5089} & \multicolumn{2}{|c|}{0.5360} & \multicolumn{2}{|c|}{0.5380} \\
\hline \multicolumn{2}{|l|}{$\Delta \mathrm{R}$-square } & \multicolumn{2}{|r|}{-} & \multicolumn{2}{|c|}{0.0271} & \multicolumn{2}{|c|}{0.0020} \\
\hline \multicolumn{2}{|l|}{$\mathrm{F}$} & \multicolumn{2}{|c|}{16.06} & \multicolumn{2}{|c|}{13.35} & \multicolumn{2}{|c|}{12.00} \\
\hline
\end{tabular}

${ }^{*} p<0.1,{ }^{* \star} p<0.05,{ }^{* \star *} p<0.01$

neering or medicine, and publicness, are statistically significant and in the expected direction. The results show that the retention rate is lower in universities located outside of Seoul and Gyeonggi-do. This anomaly may result from the poor quality of the employment rate measurement.

The R-square and robustness of these three models are quite high but do not indicate any statistically significant effect of the independent and moderating variables in the expected direction in models 2 and 3. To sum up, these results from the analysis of educational performance, employment rate and retention rate, provided no support for hypotheses 1 and 2 . 


\section{RESULTS OF RESEARCH PERFORMANCE}

\section{Number of Articles Published in Foreign Journals per Full-Time Faculty Member}

Table 5 displays the results for the number of articles published in foreign journals per full-time faculty member. Most of the control variables, such as the rate at which students take out loans for school expenses, the location of a university, the number of students per full-time faculty member, the size of organization, and whether or not the university has a school of engineering or medicine are statistically significant and in the expected direction in model 1 . All of them (except for whether or not the university has a school of engineering or medicine) remain significant in models 2 and $3 .{ }^{20}$

Table 5. Analysis of the Number of Articles Published in Foreign Journals per Full-Time Faculty Member

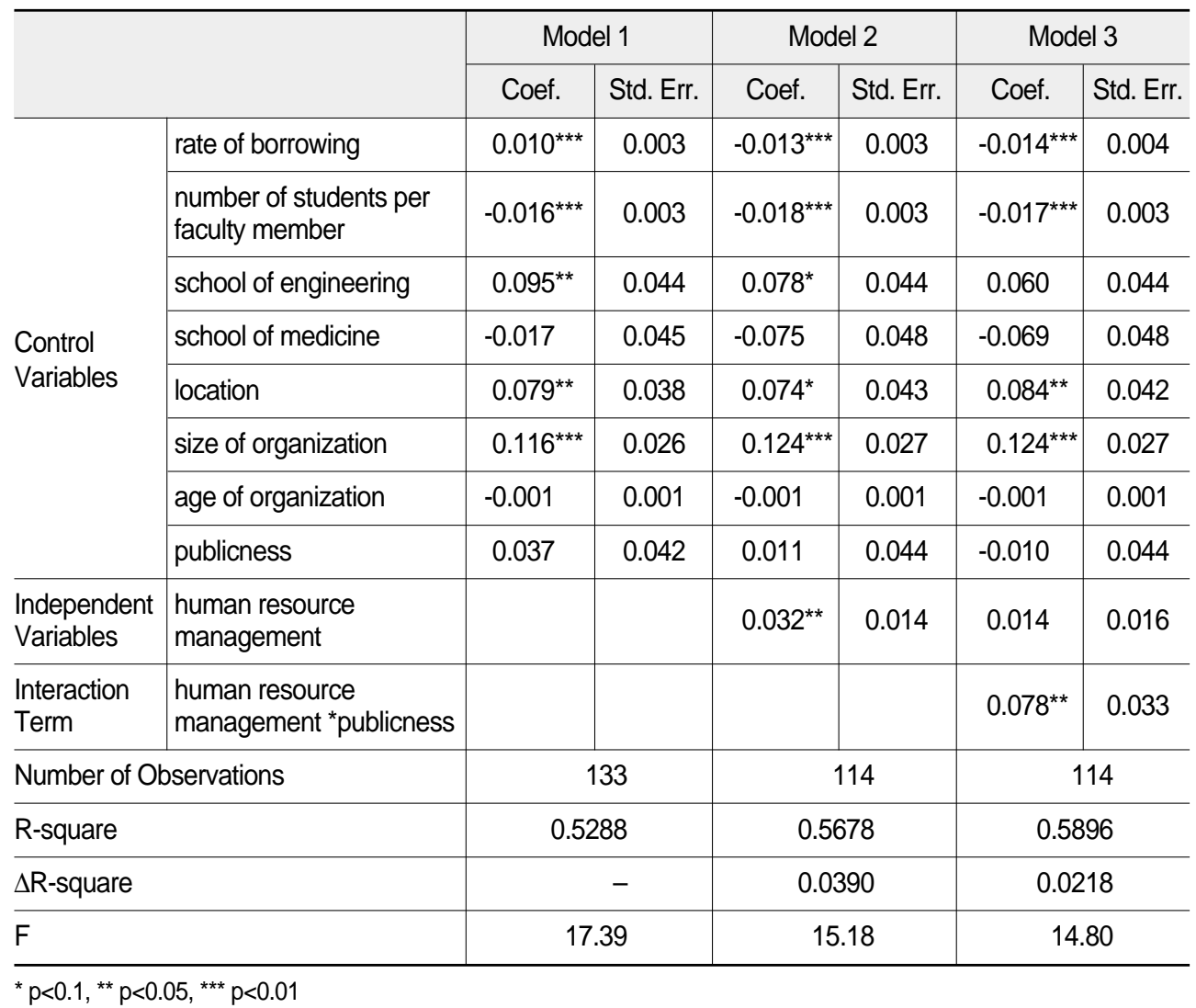


Unlike in the analyses of educational performance, all focal variables are statistically significant in this analysis. The R-square and the robustness of model 2 are also quite high, and the model accounts for $56.8 \%$ of the total variance. An additional increase in the R-square $(\Delta \mathrm{R}$-square is $0.03, \mathrm{p}<.001)$ from model 1 to model 2 was confirmed, and it is statistically significant. Model 2 provides support for hypothesis 1 that the managers in organizations that devote time and resources to human resource management will perceive higher levels of organizational performance than managers in organizations that don't. This means that this study provides evidence for the positive impact of human resource management on organizational performance.

Furthermore, model 3, which includes the interaction term, accounts for $58.7 \%$ of the total variance. The additional increase in the $\mathrm{R}$-square $(\Delta \mathrm{R}$-square is 0.0218 , $\mathrm{p}<.001$ ) from model 2 to model 3 is also statistically significant. Model 3 provides

Figure 1. The Moderating Effect of the Number of Articles Published in Foreign Journals per Full-Time Faculty Member

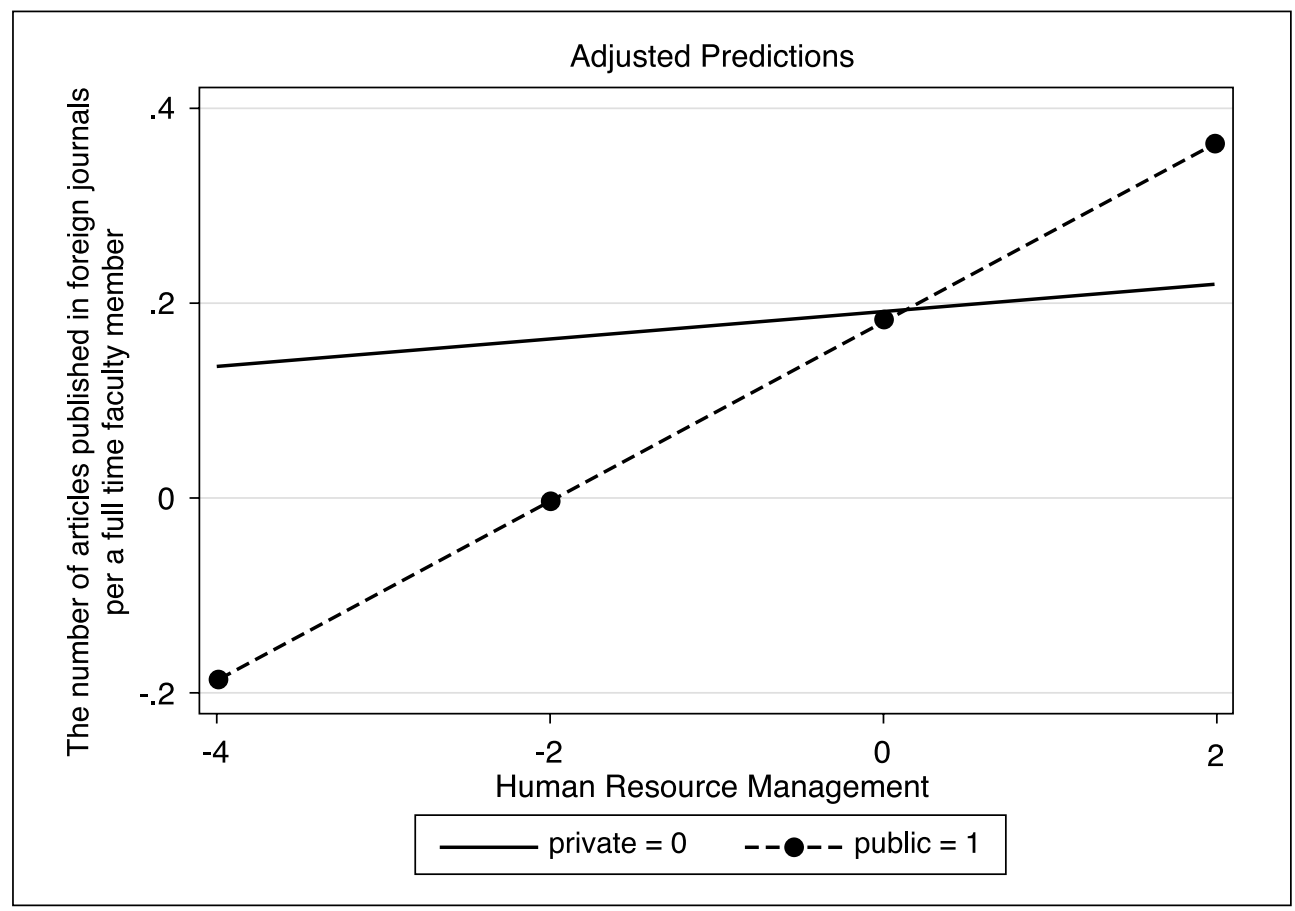

20. The rate of students taking out loans for school expenses and the number of students per full-time faculty member support Meier and O'Toole's model. The location of a university also provides support for previous research in Korea. 
support for hypothesis 2 that the moderating effect of human resource management on performance differs depending on the publicness of the organization. This means that this study also provides evidence for the moderating effect of publicness.

Figure 1 shows the moderating effect of publicness. If the top managers in both public and private universities put more effort into human resource management, the number of articles published in foreign journals per full-time faculty member in both public and private universities tends to rise, although there is a difference in magnitude between public and private organizations. The magnitude of the upward trend is much greater in public universities than in private universities.

\section{Number of Articles Published in Korean Journals per Full-Time Faculty Member}

Table 6 displays the results for the number of articles published in Korean journals per full-time faculty member. Some control variables, such as the rate at which students take out loans for school expenses, the number of students per full-time faculty member whether or not the university has a college of engineering or medicine, the age of organization, and publicness are statistically significant and in the expected direction in model 1. It provides an interesting comparison with the result from the analysis of the number of articles published in foreign journals per full-time faculty member. The age of organization and publicness are highly significant in model 1 and remain significant consistently throughout models 2 and 3 .

The results here are quite different and even contradictory to those of the analysis of the number of articles published in foreign journals per full-time faculty member. Human resource management is not statistically significant at all in model 2. However, the interaction term is statistically significant but negative in the expected direction in model 3.

The results suggest that if the top managers in private universities put more effort into human resource management, the number of articles published in Korean journals per full-time faculty member tends to decline. There are several possible explanations for this phenomenon. The confounding relationships among performance indicators (see table 2) provide hints. Table 2 shows that the correlation between the number of articles published in foreign journals per full-time faculty member and the number of articles published in Korean journals per full-time faculty member is negative and even statistically significant.

This result can be confirmed in figure 2. If the top managers in private universities put more effort into human resource management, the number of articles published in Korean journals per full-time faculty member tends to rise slightly, but in public uni- 
Table 6. Analysis of the Number of Articles Published in Korean Journals per Full-Time Faculty Member

\begin{tabular}{|c|c|c|c|c|c|c|c|}
\hline & \multicolumn{2}{|c|}{ Model 1} & \multicolumn{2}{|c|}{ Model 2} & \multicolumn{2}{|c|}{ Model 3} \\
\hline & & Coef. & Std. Err. & Coef. & Std. Err. & Coef. & Std. Err. \\
\hline \multirow{8}{*}{$\begin{array}{l}\text { Control } \\
\text { Variables }\end{array}$} & rate of borrowing & $-0.009^{* *}$ & 0.004 & -0.006 & 0.004 & -0.003 & 0.004 \\
\hline & $\begin{array}{l}\text { number of students per } \\
\text { faculty member }\end{array}$ & $0.009^{\star *}$ & 0.003 & $0.009^{\star \star}$ & 0.004 & $0.009^{* *}$ & 0.004 \\
\hline & school of engineering & $-0.136^{\star *}$ & 0.055 & $-0.116^{\star \star}$ & 0.056 & -0.088 & 0.055 \\
\hline & school of medicine & -0.040 & 0.057 & -0.050 & 0.062 & -0.059 & 0.059 \\
\hline & location & 0.070 & 0.048 & 0.003 & 0.054 & -0.012 & 0.053 \\
\hline & size of organization & 0.012 & 0.033 & 0.023 & 0.035 & 0.023 & 0.034 \\
\hline & age of organization & $0.002^{\star \star \star}$ & 0.001 & $0.003^{\star \star \star}$ & 0.001 & $0.003^{\star * \star}$ & 0.001 \\
\hline & publicness & $0.183^{* * *}$ & 0.053 & $0.210^{* \star *}$ & 0.056 & $0.245^{\star * *}$ & 0.055 \\
\hline $\begin{array}{l}\text { Independent } \\
\text { Variables }\end{array}$ & $\begin{array}{l}\text { human resource } \\
\text { management }\end{array}$ & & & -0.019 & 0.018 & 0.009 & 0.020 \\
\hline $\begin{array}{l}\text { Interaction } \\
\text { Term }\end{array}$ & $\begin{array}{l}\text { human resource } \\
\text { management *publicness }\end{array}$ & & & & & $-0.123^{\star \star \star}$ & 0.041 \\
\hline \multicolumn{2}{|c|}{ Number of Observations } & \multicolumn{2}{|c|}{133} & \multicolumn{2}{|c|}{114} & \multicolumn{2}{|c|}{114} \\
\hline \multicolumn{2}{|l|}{ R-square } & \multicolumn{2}{|c|}{0.4287} & \multicolumn{2}{|c|}{0.4697} & \multicolumn{2}{|c|}{0.5112} \\
\hline \multicolumn{2}{|l|}{$\Delta \mathrm{R}$-square } & \multicolumn{2}{|r|}{-} & \multicolumn{2}{|c|}{0.0410} & \multicolumn{2}{|c|}{0.0415} \\
\hline \multicolumn{2}{|l|}{$\mathrm{F}$} & \multicolumn{2}{|c|}{11.63} & \multicolumn{2}{|c|}{10.24} & \multicolumn{2}{|c|}{10.77} \\
\hline
\end{tabular}

${ }^{*} p<0.1,{ }^{* *} p<0.05,{ }^{* * *} p<0.01$

versities, if the top managers put more effort into human resource management, this declines.

Concerning these confounding relationships among performance indicators, Han, Jang, Han, and Yang (2008) have suggested several contextual implications related to publicness in Korean universities. They analyze the impact of the amount of government funding on the research outputs, demonstrating that the amount of government funding contributes positively to the research outputs measured by the number of articles published in foreign journals (listed in the SCI or SCOPUS), but the impact on the research outputs measured by the number of articles published in Korean journals (listed in NRFK) was not statistically significant. These results cannot be applied directly to our analysis because they used the amount of public funding as publicness rather than ownership. Nonetheless, at least it can be concluded that critically disparate 
Figure 2. The Moderating Effect of the Number of Articles Published in Korean Journals per Full-Time Faculty Member

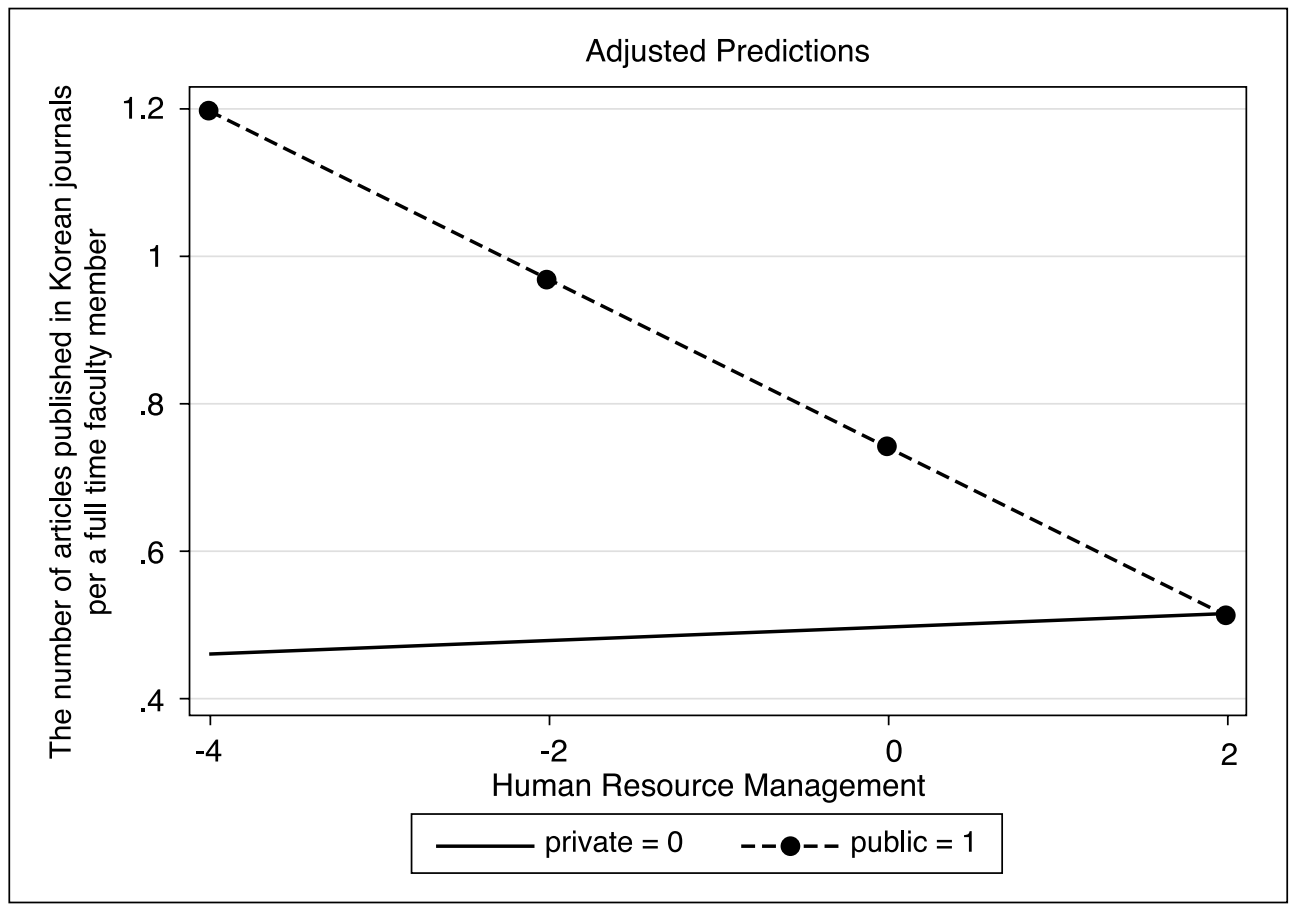

factors affect foreign and domestic research outputs, and publicness has a unique and different impact on them. In addition, it should be borne in mind that the number of articles published in Korean journals is much higher than the number of articles published in foreign journals, particularly in private universities. The Korean Educational Development Institution (KEDI, 2008) report that the average number of articles published in foreign and Korean journals are almost same in public universities, but in private universities, twice as many articles are published in Korean journals as in foreign journals. $^{21}$ This phenomenon relates to the differential impact of publicness on the

21.

\begin{tabular}{l|c|c}
\hline \multicolumn{1}{c|}{ Contents } & $\begin{array}{c}\text { Public } \\
\text { Universities }\end{array}$ & $\begin{array}{c}\text { Private } \\
\text { Universities }\end{array}$ \\
\hline average number of foreign-authored articles listed in SCI & 367 & 121 \\
\hline average number of Korean-authored articles listed in SCI & 304 & 208 \\
\hline foreign: domestic & $1: 1$ & $1: 2$ \\
\hline
\end{tabular}

Source: Kang 2014 
research outputs is beyond the scope of this study, but it should be the subject of substantial additional research.

\section{CONCLUSION}

This study has examined the external validity of O'Toole and Meier's (2011) management-performance nexus model using Korean higher education institutions as the dataset. In particular, the aim of this study has been to provide additional evidence that publicness can moderate the relationship between management and performance.

This study investigated the impact of human resource management on organizational performance using a dataset from 155 universities (four-year colleges) in Korea. I also examined the moderating effect of publicness on the relationship between human resource management and performance using ownership (that is, whether the university is public or private) as an indicator of publicness. In short, my analysis indicates that top managers' efforts to improve human resource management positively contributed to one of the research performance indicators, namely, the number of articles published in foreign journals per full-time faculty member. However, I do not observe this effect among the other three performance indicators, the number of articles published in Korean journals per full-time faculty member, the employment rate of college graduates, and the student retention rate. Further, the moderating effects of the relationship between human resource management and performance are shown in the analysis of the two research performance indicators but not in the analysis of the two educational performance indicators.

This finding does not contradict the common pattern found in most comparative studies of national contexts. Although in general this finding may seem similar to that of other research based on different nations and type of organizations, the specifics are very different. O'Toole and Meier (2011) suggest that top managers' human resource management effort positively contributes to all aspects of performance in their analysis using a dataset from Texas school organizations. However, in this article, this effect is shown for only one of four performance indicators for Korean universities.

This discrepancy may result from differences in national context (U.S. vs. Korea) and the type of organizations (school districts vs. universities). O'Toole and Meier apply their model to Denmark as well, and the findings provide no support for their model. They explain that this discrepancy may result from the difference in the national context. ${ }^{22}$ More precisely, compared to the superintendents of Texas school districts

22. O'Toole and Meier (2014) found considerable variation regarding policy field or sector in 
who have substantial managerial discretion, school managers in Denmark have less discretion due to powerful teacher unions. They explain that management matters in Texas, while it has virtually no effect in Denmark (Meier, Anderson, O'Toole, Favero, $\&$ Winter, 2015). Following this approach, public management research in Korea should pay more attention to the role of context and should seek to construct a model reflecting the contextual variance that managers in Korea confront.

This article partially shows that the human resource management in public universities is more effective than in private universities. It provides empirical evidence of the theoretical hypothesis that internal management will matter more in public organizations posited by O'Toole and Meier (2011). This finding gives us leeway to reconsider the traditional perspective that treats the limited discretion vested in public managers as the reason for the weak link between performance and management (Rainey, 2014).

Certainly, I cannot generalize the moderating effect of publicness because it is not shown for all the performance indicators. However, this outcome is reasonable due to the confounding relationships among performance indicators in this article. According to this approach, I can propose some interesting and daunting research questions. These confounding relationships among performance indicators are related to goal conflict, a subject on which further research is needed. ${ }^{23}$ Future research should explore what steps managers take to improve the level of performance in the face of goal conflict.

Numerous prominent researchers have claimed that ambiguous performance or goal conflict can have an adverse effect on organizational managers, and researchers need to attend to this aspect. For example, Moynihan (2012) stresses that if an organization

the 66 articles they surveyed that conducted empirical studies of management and performance. The logic of considering context relative to the impact of management on public organizational performance is that it conditions the relationship between management and performance (O'Toole \& Meier, 2014). In a general theory, they postulate 23 hypotheses pertaining to the moderating or intervening effect of context on the relationship between management and performance.

23. Chun (2004) introduces the concept of goal conflict in the chapter of his book on priority goal ambiguity because it is similar to priority goal ambiguity. Priority goal ambiguity refers to the level of interpretive leeway in deciding on priorities among multiple goals. Goal conflict can be divided into two dimensions, direct and indirect. Direct goal conflict is the confounding phenomenon wherein there are only two goals and hence if one is chosen then the other is abandoned. Indirect goal conflict refers to the latent competition that arises when an organization has multiple goals and must spread resources around. According to this approach, indirect goal conflict can be measured by counting the number of goals in an organization in the same way one does in assessing priority goal ambiguity. 
has multiple goals, then performance will not be unidimensional. He also asserts that even there are likely to be negative correlations between performance factors associated with one aspect of performance, there may not be such correlations associated with others. If managers are confronted with multiple goals and there is ambiguity in determining their priority (Chun \& Rainey, 2005), they can be directed to pay more attention to one goal and less attention to others that may in fact be no less important (Moynihan, 2012). This can happen differentially depending on publicness, and it will matter more in public universities than in private universities. Consequently, I assume that this difference will influence the overall results of my analysis.

In short, a differential moderating effect on the performance of universities cannot fully understood until research on ambiguous performance or goal conflict is carried out. ${ }^{24}$ This is another implication of this article and guides the direction for future research.

\section{REFERENCES}

Ahn, T. S., Cho, G. J., \& Park, T. S. 1998. Efficiency and influence in Korean universities. Korean Accounting Journal, 23(2): 183-216.

Andersen, S. C., \& Mortensen, P. B. 2010. Policy stability and organizational performance: Is there a relationship? Journal of Public Administration Research and Theory, 20(1): 1-22.

Andrews, R., Boyne, G. A., \& Walker, R. M. 2011. Dimensions of publicness and organizational performance: A review of the evidence. Journal of Public Administration Research and Theory, 21(supp. 3): i301-i319.

Arnaud, S., \& Wasieleski, D. M. 2014. Corporate humanistic responsibility: Social performance through managerial discretion of the HRM. Journal of Business Ethics, 120(3): 313-334.

Avellaneda, C. N. 2009. Municipal performance: Does mayoral quality matter? Journal of Public Administration Research and Theory, 19(2): 285-312.

Bae, J. W., Yoon, G. W., \& Chun, G. W. 2012. Methods for building a performance management system in Korean universities: Comparative analysis by the university types. Journal of the Social Science Research Institute, 36(2): 51-90.

Bertelli, A. M., \& Lynn, L. E. 2006. Madison's managers: Public administration and

24. This idea is reflected in one of the 23 hypotheses that O'Toole and Meier (2014) postulate. "As goal ambiguity (and conflict) increase(s), the marginal contribution of a given level of management declines." 
the Constitution. Baltimore, MD: Johns Hopkins University Press.

Boyne, G., Poole, M., \& Jenkins, G. 1999. Human resource management in the public and private sectors: An empirical comparison. Public Administration, 77(2): 407-420.

Bozeman, B. 1987. All organizations are public. Frederick, MD: Beard Books.

Brinkman, P. T., \& Leslie, L. L. 1986. Economies of scale in higher education: Sixty years of research. Review of Higher Education, 10(1): 1-28.

Budhwar, P. S., \& Boyne, G. 2004. Human resource management in the Indian public and private sectors: An empirical comparison. International Journal of Human Resource Management, 15(2): 346-370.

Burtless, G. T. 1996. Does money matter? The effect of school resources on student achievement and adult success. Washington, DC: Brookings Institution Press.

Cho, T., \& Yoon, S. 2009. Human resource management, individualism-collectivism, and individual performance among public employees: A test of the main and moderating effects. Korean Journal of Policy Studies, 23(2): 57-78.

Choi, J. Y. 2008. A study of the quality of Korean universities. Pt. 2. Korean Educational Development Institution, Research Paper RR 2008-14.

Chun, Y. H. 2004 Concept, measurement, and validation = goal ambiguity in public organizations. Korean Public Administration Review, 38(5): 49-65.

Chun, Y. H., \& Kum, H. S. 2011. A study of the determinants of performance in Korean educational organizations. Korean Journal of Public Administration, 49(2), 235-266.

Chun, Y. H., \& Rainey, H. G. 2005. Goal ambiguity and organizational performance in US federal agencies. Journal of Public Administration Research and Theory, 15(4): 529-557.

Daft, R. 2012. Organization theory and design. Melbourne, Australia: Nelson.

Dundar, H., \& Lewis, D. R. 1998. Determinants of research productivity in higher education. Research in Higher Education, 39(6): 607-631.

Favero, N., Meier, K. J., \& O'Toole, L. J. 2014. Goals, trust, participation, and feedback: Linking internal management with performance outcomes. Journal of Public Administration Research and Theory, 26(2) 327-343.

Feeney, M. K., \& Rainey, H. G. 2010. Personnel flexibility and red tape in public and nonprofit organizations: Distinctions due to institutional and political accountability. Journal of Public Administration Research and Theory, 20(4): 801-26.

Guest, D. E., \& Woodrow, C. 2012. Exploring the boundaries of human resource managers' responsibilities. Journal of Business Ethics, 111(1): 109-119.

Han, D. S., Jang, D. H., Han, S. H., \& Yang, J. M. 2008. Analysis of the impact of government funding on research performance. Korea Public Administration 
Review, 42(4): 265-290.

Hashimoto, K., \& Cohn, E. 1997. Economies of scale and scope in Japanese private universities. Education Economics, 5(2): 107-115.

Ingraham, P. W., Selden, S. C., \& Moynihan, D. P. 2000. People and performance: Challenges for the future public service - the report from the Wye River Conference. Public Administration Review, 60(1): 54-60.

Jacobs, R., \& Washington, C. 2003. Employee development and organizational performance: A review of literature and directions for future research. Human Resource Development International, 6(3): 343-354.

Jang, S. M. 2002. Economics of university education. Quarterly Journal of Labor Policy, 2(1): 47-79.

Jencks, C., \& Phillips, M. 1998. America's next achievement test: Closing the blackwhite test score gap. American Prospect, 40: 44-53.

Jo, Y. I., Kim J. H., Han. W. L., \& Jo. Y. J. 2015. Differences between and combinations of moderating and mediating effects: Definitions and statistical testing. Korean Journal of Clinical Psychology, 34(4): 1113-1131.

Johansen, M., \& LeRoux, K. 2013. Managerial networking in nonprofit organizations: The impact of networking on organizational and advocacy effectiveness. Public Administration Review, 73(2): 355-363.

Kang, C. D. 2014. A comparative study of competitiveness between Korean national and private universities. Korea Educational Review, 20(3): 301-323.

Kim, B. J. 2009. Developing formula indicators based on AHP for financing universities. Journal of Economics and Finance of Education, 18 (1): 225-245.

Kim, G. I., Shim, J. S., \& Lee, H. S. 2013. A study of the impact of a university's capacity on performance. Journal of the Korean Association for Policy Analysis and Evaluation, 23(2): 63-86.

Kwak, J. S. 2013. How to improve the indices for the employment rate used in the evaluation of universities. Journal of the Korean Society for Educational Evaluation, 26: 181-215.

Koch, M. J., \& McGrath, R. G. 1996. Improving labor productivity: Human resource management policies do matter. Strategic Management Journal, 17(5): 335-354.

Lee, D. G. 2001. Management and accounting in private Universities. Seoul: SeonHakSa.

Lee, D. G., Kwak, Y. J., \& Lee, S. D. 2003. A model for account balancing and business management. Seoul: Korea Foundation for the Promotion of Private Schools.

Lee, G. H., \& Kim, T. I. 2007. Gender, college rankings and majors, and earnings in Korea. Korean Journal of Educational Research, 45(3): 167-197.

Lewis, R. G., \& Smith, D. H. 1994. Total quality in higher education. Delray Beach, FL: St. Lucie Press. 
Li, L. X. 2000. An analysis of sources of competitiveness and performance of Chinese manufacturers. International Journal of Operations and Production Management, 20(3): 299-315.

Lloyd, P. J., Morgan, M. H., \& Williams, R. A. 1993. Amalgamations of universities: Are there economics of scale or scope? Applied Economics, 25(8): 1081-1092.

Lovegrove, B. G., \& Johnson, S. D. 2008. Assessment of research performance in biology: How well do peer review and bibliometry correlate? Bioscience, 58(2): 160-164.

Lynn, L. E., Jr. 2006. Public management: Old and new. New York: Routledge.

May, P. J., \& Winter, S. C. 2009. Politicians, managers, and street-level bureaucrats: Influences on policy implementation. Journal of Public Administration Research and Theory, 19(3): 453-476.

Maynard-Moody, S. W., \& Musheno, M. C. 2003. Cops, teachers, counselors: Stories from the front lines of public service. Ann Arbor: University of Michigan Press.

McGregor, D. 1960. The human side of enterprise. New York: McGraw-Hill.

Meier, K. J., Anderson, S. C., O’Toole, L. J., Favero, N., \& Winter, S. C. 2015. Taking managerial context seriously: Public management and performance in US and Denmark schools. International Public Management Journal, 18(1): 130-150.

Meier, K. J., \& Hicklin, A. 2008. Employee turnover and organizational performance: Testing a hypothesis from classical public administration. Journal of Public Administration Research and Theory, 18(4): 573-590.

Meier, K. J., \& O'Toole, L. J. 2001. Managerial strategies and behavior in networks: A model with evidence from US public education. Journal of Public Administration Research and Theory, 11(3): 271-294.

Meier, K. J., \& O’Toole, L. J. 2003. Public management and educational performance: The impact of managerial networking. Public Administration Review, 63(6): 689-699.

Meier, K. J., \& O'Toole, L. J. 2005. Managerial networking issues of measurement and research design. Administration and Society, 37(5): 523-541.

Meier, K. J., \& O'Toole, L. J. 2007. Modeling public management: Empirical analysis of the management-performance nexus. Public Management Review, 9(4): 503-527.

Meier, K. J., \& O'Toole, L. J. 2011. Comparing public and private management: Theoretical expectations. Journal of Public Administration Research and Theory, 21(3): 1283-1299.

Moynihan, D. P. 2012. Identifying the antecedents to government performance: Implications for human resource management. In B. G. Peters \& J. Pierre (eds.), The SAGE Handbook of Public Administration (pp. 71-86). Thousand Oaks, CA: Sage. 
Nicholson-Crotty, S., Theobald, N. A., \& Nicholson-Crotty, J. 2006. Disparate measures: Public managers and performance-measurement strategies. Public Administration Review, 66(1): 101-113.

Nigro, L. G., \& Kellough, J. E. 2006. The states and civil service reform: Lessons learned and future prospects. In L. G. Nigro \& J. E. Kellough (eds.), Civil Service Reform in the States: Personnel policy and politics at the subnational level (pp. 315-324). Albany: State University Press of New York.

Oh, J. J. 2010. The effects of the size and location of private universities on management performance. Journal of the Korea International Accounting Association, 31: 265-284.

O’Toole, L. J., \& Meier, K. J. 2004. Public management in intergovernmental networks: Matching structural networks and managerial networking. Journal of Public Administration Research and Theory, 14(4): 469-494.

O'Toole, L. J., \& Meier, K. J. 2006. Networking in the penumbra: Public management, cooptative links, and distributional consequences. International Public Management Journal, 9(3): 271-294.

O’Toole, L. J., \& Meier, K. J. 2009. The human side of public organizations contributions to organizational performance. American Review of Public Administration, 39(5): 499-518.

O’Toole, L. J., \& Meier, K. J. 2011. Public management: Organizations, governance, and performance. New York: Cambridge University Press.

O'Toole, L. J., \& Meier, K. J. 2015. Public management, context, and performance: In quest of a more general theory. Journal of Public Administration Research and Theory, 25(1): 237-256.

O’Toole, L. J., Walker, R. M., Meier, K. J., \& Boyne, G. A. 2007. Networking in comparative context: Public managers in the USA and the UK. Public Management Review, 9(3): 401-420.

Perry, J. L., \& Rainey, H. G. 1988. The public-private distinction in organization theory: A critique and research strategy. Academy of Management Review, 13(2): 182-201.

Rainey, H. G. 2014. Understanding and managing public organizations. San Francisco: Jossey-Bass.

Sayre, W. 1958. The unhappy bureaucrats: Views ironic, hopeful, indignant. Public Administration Review, 18(3): 239-245.

Selden, S. C., \& Jacobson, W. 2007. Government's largest investment: Human resource management in states, counties, and cities. In P. W. Ingraham (ed.), Pursuit of performance: Management systems in state and local government (pp. 82-116). Baltimore, MD: Johns Hopkins University Press.

Shafritz, J. M., Rosenbloom, D. H., Riccucci, N. M., Knaff, K. C., \&d Hyde, A. C. 
2001. Personnel management in government: Politics and process. 5th ed. New York: Marcel Dekker.

Song, M. Y., \& Chun, Y. H. 2014. Organizational management and job satisfaction: Hierarchical linear model analysis of Korean education. Korean Public Administration Review, 48(4): 109-132.

Stillman, R. J. 1998. Creating the American state: The moral reformers and the modern administrative world they made. Tuscaloosa: University of Alabama Press.

Tummers, L., \& Bekkers, V. 2014. Policy implementation, street-level bureaucracy, and the importance of discretion. Public Management Review, 16(4): 527-547.

Walker, R. M., Boyne, G. A., \& Brewer, G. A. (eds.). 2010. Public management and performance: Research directions. New York: Cambridge University Press.

Williamson, O. E. 1975. Markets and hierarchies. New York: Free Press.

Wilson, J. Q. 1989. Bureaucracy: What government agencies do and why they do it. New York: Basic Books.

Wood, S. 1999. Human resource management and performance. International Journal of Management Reviews, 1(4): 367-413. 